that protein synthesis can occur in both nucleus and cytoplasm. It also follows that the nucleus can meet the energy requirements of protein synthesis. In this connexion it has been found that the isolated thymus nucleus is endowed with systems which generate high-energy phosphate bonds.

[July 26

'Allfrey, V. G., Proc. U.S. Nat. Acad. Sci., 40, 881 (1954).

"Stern, H., and Mirsky, A. E., J. Gen. Physiol., 37, 177 (1953).

${ }^{3}$ Allfrey, V. G., Stern, H., Mirsky, A. E., and Saetren, H., J. Gen. Physiol., 35, 529 (1952).

+ Stern, H., Allfrey, V. G., Mirsky, A. E., and Saetren, H., J. Gen.

'Allfrey, V. G., and Mirsky, A. E., Science, 121, 879 (1955).
'Brachet, J., Arch. Biol., 53, 207 (1941).

"Caspersson, T., "Cell Growth and Cell Function" (Norton. New York, 1950).

${ }^{8}$ Gale, E. F., and Folkes, J. P., Biochem. J., 55, xi (1953).

-Allfrey, V. G., Daly, M. M., and Mirsky, A. E., J. Gen. Physiol., 37, 157 (1953).

10 Daly, M. M., and Mirsky, A. E., J. Gen. Physiol., 38, 405 (1955).

${ }^{11}$ Gale, E. F., and Folkes, J. P., Biochem. J., 53, 493 (1953).

${ }^{2}$ Santisteban, G. A., and Dougherty, T. F., Endocrin., 54, 130 (1954).

${ }^{13}$ Allfrey, V. G., Daly, M. M., and Mirsky, A. E., J. Gen. Physiol., $38,415(1955)$.

14 Siebert, G., Lang, K., Lucius, S., and Rossmüller, G., Biochem. Z. 324, 311 (1953).

is Hurlbert, R. B., Schmitz, H., Brumm, A. F., and Potter, V. R. J. Biol. Chem., 209, 23 (1954).

\title{
THE VENEZUELAN INSTITUTE FOR NEUROLOGY AND BRAIN RESEARCH
}

By Dr. GEOFFREY H. BOURNE

London Hospital Medical College

GITUATED in the beautiful mountains surrounding $S$ Caracas, the capital of Venezuela, and only $12 \mathrm{~km}$. away from the centre of the city, is an Institute which represents the first stage of a great scheme for neurological research.

On January 1, 1955, the 5,000-ft. mountain on which this Institute has been placed was virgin territory; since then, the prodigious efforts of Dr. Humberto Fernandez-Moran have resulted in the flattening of the top of the mountain, the building of an $800-\mathrm{kW}$. electric power station with specially controlled voltage, a water-supply system which mcludes an artificial lake of some 6 million litres capacity, and what is described as the 'Pilot' unit of the Institute, together with residences for the staff. On December 2 this first section of the new Institute was being opened by the President of Venezuela, General Marcos Perez Jimenez, less than a year from the arrival of the first bulldozer on the mountain top.

This first stage of the plan has already cost three million dollars, but much more will be spent before the entire project is completed. This first part contains laboratories for research into nerve ultrastructure, neurophysiology, biophysics, biochemistry and biomathematics. In addition, there are a large library, several workshops and ten residential units for scientific personnel and assistants. A guest house for visitors from abroad is also incorporated into the design. Further development of the Institute envisages a large building for the Neurotropic Virus Research Unit, a large radiation laboratory which will be equipped with a nuclear reactor for medical research, and further buildings for biochemistry, biomathematics and experimental neuropharmacology. It is proposed ultimately to have a hospital of two

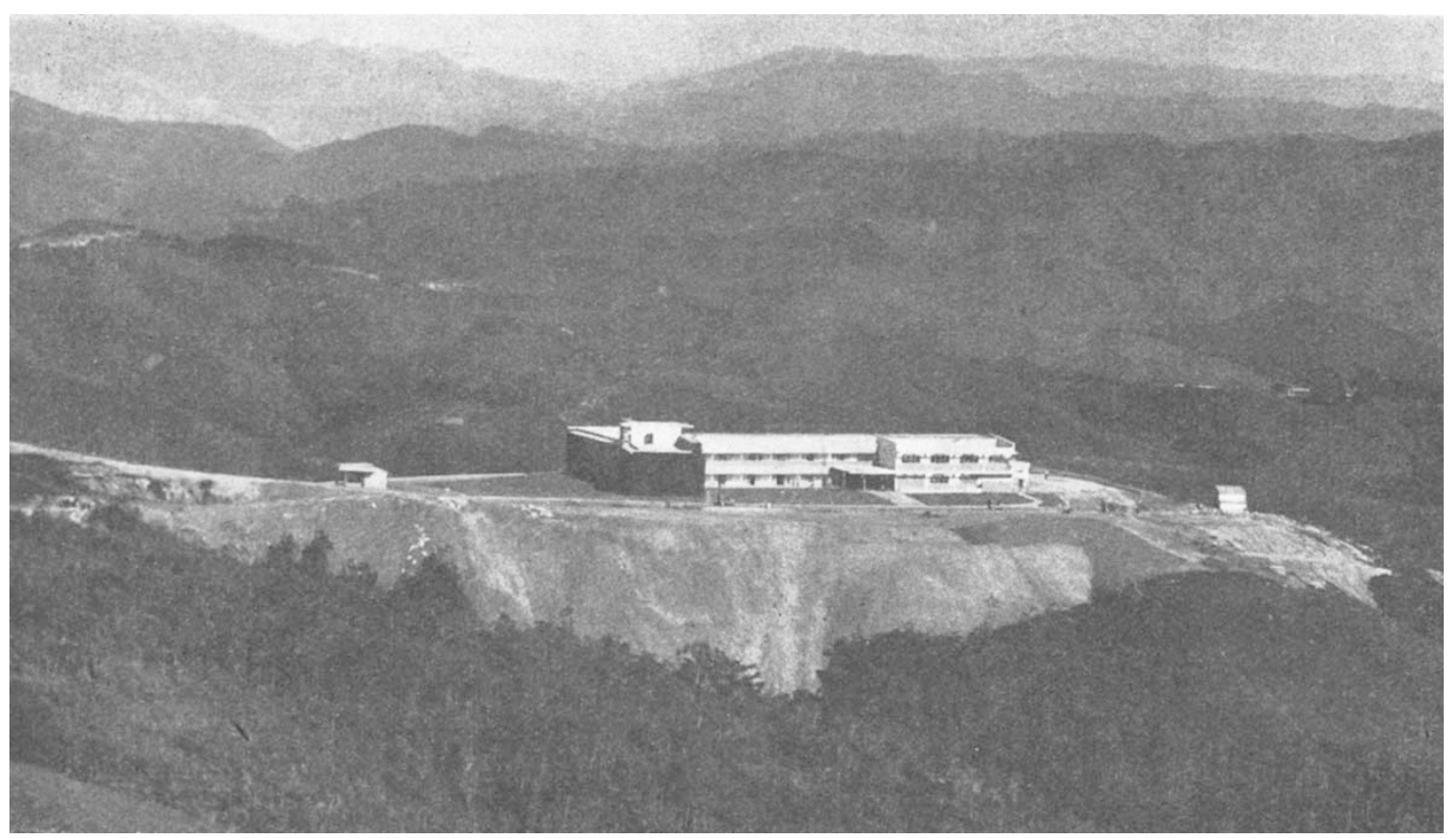

Fig. 1. The Venezuelan Institute for Neurology and Brain Research 


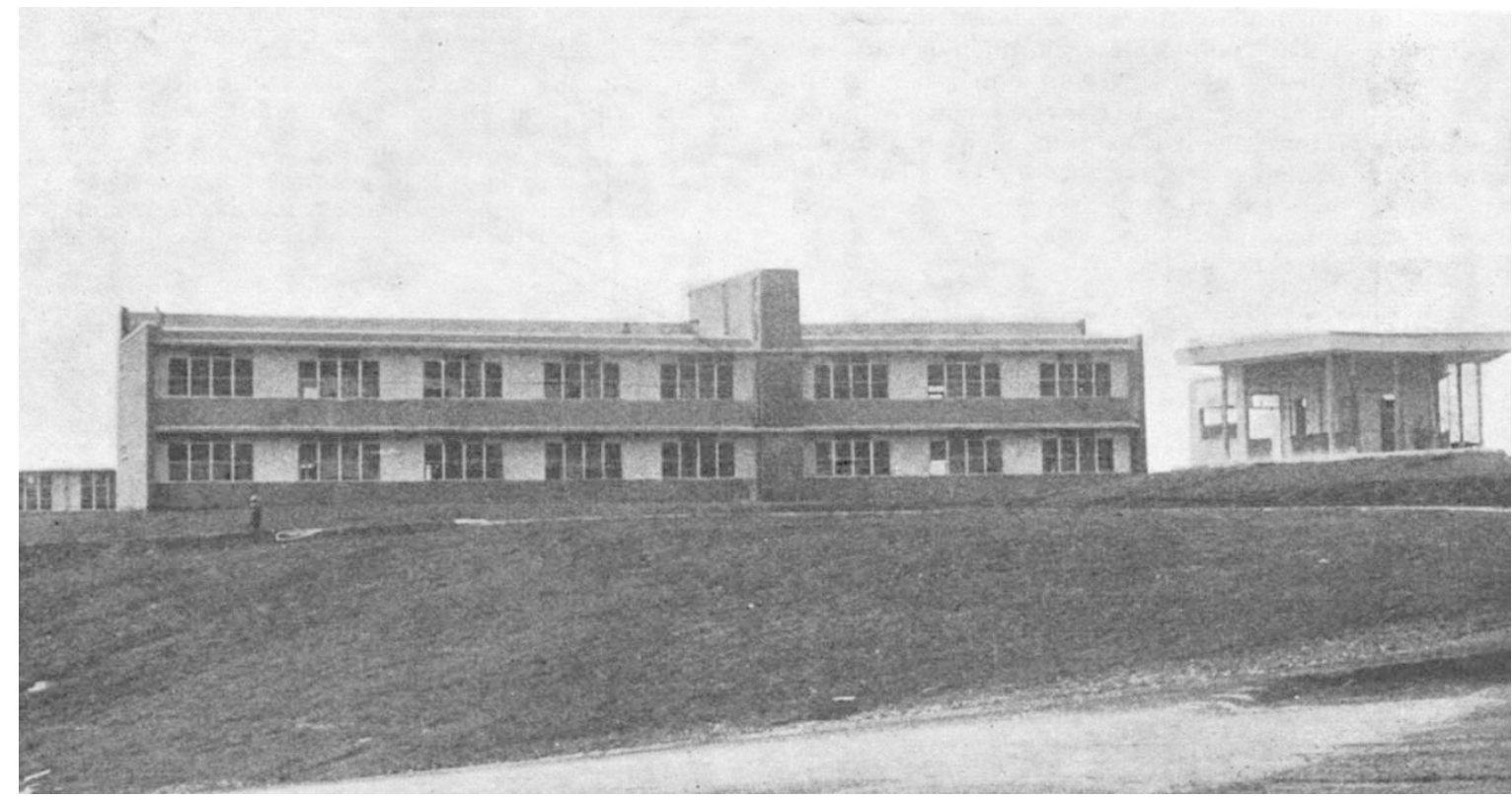

Fig. 2. First building of IVNIC (Venezuelan Institute for Neurology and Brain Research) containing : (1) Department of Nerve
Uitrastructure (equipped with three electron microscopes) (2) Department of Neurophysiology: (3) Neurotropic Virus Research Ultrastructure (equipped with three electron microscopes); (2) Department of Neurophysiology; (3) Neurotropic Virus Research
Unit; (4) Department for Nuclear Magnetic Resonanee Studies; (5) Department of Biophysics; (6) Department of Biomathematics

hundred beds similar to the Research Hospital at the National Institutes of Health in Bethesda, U.S.A. In fact, the Institute was founded last year (April 29, 1954) by decree of the President of Venezuela as an autonomous government agency similar in status to the National Institutes of Health, and in many respects to the National Institute for Medical Research in Great Britain.

The object of the Institute goes beyond being simply a national institution; it is hoped that it will become a regional research centre in neurology in South America and eventually an international research and training centre in this field. In many respects it is strategically situated for this purpose, being only seven to eight hours away by aeroplane from New York and fifteen to eighteen hours away from Britain and Western Europe. Close contact with the United States has already been established by the signature on June 14 last of an agreement between the two countries under the terms of which the United States will furnish Venezuela and the Institute with certain radioactive materials and will supply information on the design, construction, operation and use of nuclear reactors for research. The U.S. Atomic Energy Commission, under the terms of this agreement, has also agreed to lease the Venezuelan Government up to $6 \mathrm{kgm}$. of contained uranium-235 in uranium enriched up to a maximum of 20 per cent uranium-235.

The proposed intermational character of the Institute has boen emphasized by the first staff appointments : Dr. Gunnar Svaetichin, of the Karolinska Institute in Sweden, has already arrived in Caracas to take charge of the Department of Neurophysiology, which has been organized and equipped especially to work with the refined microelectrode techniques with which Dr. Svaetichin carried out pioneer work in Sweden. In addition to this, a department devoted to the application of nuclear magnetic resonance technique to the study of paracrystalline biological components like the myelin sheath of nerves is being organized with the collaboration of Dr. P. Dennis, of the University of Geneva. Full staffing of the various departments of the Institute will be a slow process, and will obviously have to be carried out with care. Those who do go to the new Institute may well find that the perpetual springlike climate of the mountain-top, on which the Institute lies, the feeling of peaceful dotachment from the world engendered by a mountainous habitat, the congenial colleagues and lack of financial worries provided by a generous salary, will provide a unique atmosphere in which their hypotheses and theories can be thought over, discussed and finally put to the test.

Providing an adequate library for the staff is a problem which the Institute will need to solve. Back numbers of many journals would be difficult to obtain; but it is proposed for this purpose to build up a collection of microfilms of back numbers. The policy of the library will also be to invest in current journals rather than books, since books are static, rapidly becoming out of date, whereas journals are the life-stream of advaneing knowledge. The equipping of the Institute will also be important; but donors have been generous for this purpose, and the researches on fine structure of nerves will have the benefit, for example, of three electron microscopes.

A description of this remarkable new Institute would be incomplete without some reference to its initiating genius and first director, Dr. FernandezMoran. Dr. Fernandez-Moran graduated in medicine in Munich and later re-qualified at the Central University, Caracas. Afterwards he took a Ph.D. in physics in the University of Stockholm. He was a fellow in neurology at George Washington University, Washington, D.C., assistant in neurosurgery at the Serafimerlas Clinic, Stockholm, and Research Fellow at the Institute for Cell Research, Karolinska Institute, Stockholm, and assistant professor of cell research in the same Institute. As well as being the first director of the new Institute, he holds the chair 
of biophysics at the Central University, Caracas. His electron microscope studies have established his reputation as an authority on the sub-microscopic organization of vertebrate nerve fibres. Much of this work was due to his development of a microtome for cutting sections of nervous and other tissues (including undecalcified bones and teeth) at thicknesses of $100 \mathrm{~A}$. or less, which are necessary for good electron microscope investigations. For this machine he also designed a diamond knife which could be made from industrial diamonds. In the Institute, Dr. Fernandez-Moran will take charge of the work on fine structure of nervous tissue, and he has established a special department to continue the development work on the diamond knife and on microtomes to use with them.

During my visit to the Institute last summer, it was a revelation to see the energy and speed with which Dr. Moran tackled and coped with the innumerable details of equipping and starting the Institute in time for the opening.

Venezuela is in an extremely fortunate financial position due to the exploitation of her oil and other natural resources, and she is extremely fortunate that she has at such a moment someone like Dr. Fernandez-Moran, who was able to conceive and to execute such a remarkable scheme, and an enlightened Minister of Health and President, who were farsighted enough to see that money invested in this way would benefit not only Venezuela itself but ultimately the rest of the world as well. The Venezuelan Institute for Neurology and Brain Research is a practical step forward in international scientific research.

\section{OBITUARIES}

\section{Dr. J. W. Nicholson, F.R.S.}

DR. J. W. Nicholson, an outstanding mathematician and man of science, died on October 10 , aged seventy-three. He was the eldest son of the late J. W. Nicholson, of Redcar, Yorkshire, and began the serious study of mathematics and physical science at the University of Manchester. Later, he entered Trinity College, Cambridge, where his brilliant career began. He was 12th Wrangler in 1904 and Isaac Newton Student in 1906. In 1907 he was Smith's Prizeman. He was Adam's Prizeman twice-in 1913 and 1917. He lectured at the Cavendish Laboratory and later at The Queen's University, Belfast.

In 1912 he was appointed professor of mathe. matics in the University of London, King's College, and occupied this chair until 1921, when he became tutor at Balliol College, Oxford, where he was director of studies in mathematics and physics until serious illness forced him to retire in 1930 .

Nicholson was one of the most brilliant mathematicians and astrophysicists of his time. In 1917 he was elected into the Royal Society. He was also a Fellow of the Royal Astronomical and the London Mathematical Societies, past president of the Röntgen Society, a former vice-president of the Physical Society and a member of the Société de Physique. He was an excellent lecturer and teacher, and probably no teacher in King's College in his time was so much appreciated and admired by his students and colleagues as he was.

Nicholson's scientific achievements are much more important than is generally realized in these days: the elucidation of the electronic structure of atoms owes as much to Nicholson as to any other one man. Before his appointment to King's College, he became interested in certain nebular spectra (the nebula in Orion among others) and the spectrum of the solar corona; and the first of a most remarkable sequence of papers on this subject appeared in the Monthly Notices of the Royal Astronomical Society (72, 49; 1912), entitled "The Spectrum of Nebulium". In this he attributed certain nebular speetral lines to a primitive type of atom which he named nebulium. This he imagined to consist of a small central massive positively charged nucleus with four electrons travelling around it on the same circular orbit. $\mathrm{He}$ was thus enabled to account for certain spectral lines which, it seemed, could not be ascribed to hydrogen or helium. His work was inspired by Clerk Maxwell's famous paper on Saturn's rings. He was, in fact, able to identify a large number of nebular spectral lines with those which his nebulium would be expected to emit. Indeed, he predicted a nebular spectral line the wave-length of which he calculated to be $4352.9 \mathrm{~A}$. before it was observed. It was later observed and measured by Prof. F. J. M. Stratton, who estimated it to be $4353 \cdot 3 \mathrm{~A}$.

Perhaps the most remarkable feature of Nicholson's work was the discovery that angular momentum is an integral multiple of $h / 2 \pi$. There is no doubt that this work inspired his pupil, Niels Bohr, to explore the consequences of assuming the hydrogen atom to have a single electron travelling in a circle around a massive nucleus, and it was certainly part of the inspiration of the $\int p \mathrm{~d} q=n h$ condition enunciated by one of his colleagues at King's College and which was later adopted by Bohr.

One must not omit to mention the important work in which Nicholson collaborated with the distinguished spectroscopist, Sir Thomas Merton, and which was published in the Philosophical Transactions of the Royal Society (A, 216, 459 ; 1916 ; A, $217,237$; 1917 ; and $A, 220,137 ; 1919)$. It dealt with the distribution of intensity in broadened spectral lines and with intensity relations in the spectra of hydrogen and helium.

Nicholson was a friendly and generous man who took great pleasure in being helpful to both students and colleagues. He was a man of high character and in that respect reminded me of our colleague, $H$. Stanley Allen, and of the great Max Planck. All of us who knew him were deeply distressed by his tragic illness. As a mathematician he impressed me as very sound, and I learned more from him than from any other man, with the exception, perhaps, of the German mathematician, Carl Noumann. I shall always treasure his menory.

Nicholson married Dr. Dorothy W'rinch, Fellow of Girton College, Cambridge, in 1922, and had one daughter; the marriage was dissolved in 1938.

WM. WILSON

\section{Mr. Alexander Keiller}

Alexander KeIller, who died at the end of September at the age of sixty-five, was one of the long line of distinguished amateur British archæologists which goes back to Aubrey and Stukeley. of these perhaps the greatest was Pitt-Rivers, on whom Keiller, like him with leisure and abundant means at his disposal, admittedly modelled his own work. 